\title{
Architecture of Kalyana Pasupatheswarar Temple, Karur
}

\section{OPEN ACCESS}

Manuscript ID:

ASH-2020-08013205

Volume: 8

Issue: 1

Month: July

Year: 2020

P-ISSN: 2321-788X

E-ISSN: 2582-0397

Received: 07.05.2020

Accepted: 18.06.2020

Published: 02.07.2020

Citation:

Suresh Kumar, P.

"Architecture of Kalyana

Pasupatheswarar

Temple, Karur.” Shanlax

International Journal

of Arts, Science and

Humanities, vol. 8, no. 1, 2020, pp. 180-186.

DOI:

https://doi.org/10.34293/

sijash.v8i1.3205

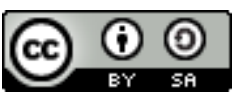

This work is licensed under a Creative Commons Attribution-ShareAlike 4.0 International License

\section{P. Suresh Kumar}

Assistant Professor, Department of History (SF)

Kandasami Kandar's College, Paramathi Velur, Namakkal, Tamil Nadu, India

\begin{abstract}
Karur Kalyanapasupatheswarar temple is one of the most remarkable temples of the Chola period. The temple stands majestically on the western bank of the river Caveri, the gigantic structure drawing the attention of the visitors. The Kalyanapasupatheswarar temple, Karur, has been attempted in the succeeding pages. There is nothing special in such legends, which are associated with many religious centers of the country. But in the present context, what is noteworthy is the fact that such legends seem to have gained currency in a much early period, say that of the Cholas, for some sculptures depicting these stories are found carved on the gopuras, walls, and pillars which had come into existence by then. The sculptors were making use of such stories for the depiction of sculptural art. But later, these stories were collected, and with additions and distortions, they came to be associated with the place.
\end{abstract}

Keywords: Karur Kalyanapasupatheswarar, Vimana, Garbhagriha, Tiruchchurrumaligai and Vijayanagar rulers

\section{Introduction}

Karur Kalyana Pasupatheswarar temple is one of the most remarkable temples of the Chola period. The temple stands majestically on the western bank of the river Caveri, the gigantic structure drawing the attention of the visitors.

This magnificent temple which faces east covers a spacious rectangular ground measuring 280x242 ft. It is dedicated to Lord Siva, called Abhiramesvarar. The entire complex, which has been built by Agama Sastras, comprised two enclosures. The temple of Kalyanapasupatheswarar (main deity) is facing east, and the Muthambigai temple of His consort is facing west as a separate temple just opposite to the Kalyanapasupatheswarar temple. The innermost prakara encloses a central shrine and several sub-shrines, all of which are encompassed by a concentric wall. The innermost enclosure wall is higher than the other walls of this temple. On the eastern side, one towering entrance with the gopura and the western side one dwarf gopura providing access into the inner courtyard.

Mahamandapa of the central shrine garbhagriha, an antarala, ardhamandapa and another aptarala and the mukhamandapa and palliarai in the inner prakara. In the second prakara a flag staff, balipitha and a Nandi mandapa are erected on an axial line.

On the northern side of the second prakara is found a hundred pillared mandapa (Kalyana mandapa). The madaippalli is housed in the southeastern corner of the second prakara. All these structures are enclosed by a wall with an entranceway in the cardinal point of the eastern direction.

\section{The Central shrine}

The east oriented central shrine of Kalyana pasupatheswarar is square in plan with the parts of a garbhagriha, an antarala, two ardhamandapa, another 
antarala, and a mukhamandapa in the axial line. In front of the mukhamandapa, there is a later mahamandapa added at a later period. The whole complex measures $75 \mathrm{ft}$. (22.86 m) from east to west. There is no epigraphical or literary data available to date this complex, and thus, we have to depend only on the architectural style of the temple structure. The square garbhagriha is in the form of a square $20 \mathrm{ft}$. $(6.10 \mathrm{~m})$ aside. It has a svayambhu linga mounted on the circular avudaiyar occupying the center of the floor of the garbhagriha. The name of the presiding deity is referred to in inscriptions as Paramaswami, ${ }^{1}$ Mahadevar, ${ }^{2}$ Alagiyanayanar, ${ }^{3}$ Aludaiyar ${ }^{4}$ and Alvar ${ }^{5}$. At present, the main deity is called Abhiramesvarar ${ }^{6}$.

The inner surface of the garbhagriha is dimly plain, while the outer surface is lavishly visible with the finest works of art and architecture.

The vimana built under the Dravidan type comprises six divisions from bottom to top, namely, adhisthana, bhitti, prastara, griva, sikhara, and stupika. The upapitha, that is, triyanga upapitha consisting of upana, kantha, and vajana forms the lowest part of the vimana. Padabandha adhisthana stands on the upapitha. The adhisthana carries a jagati, which is high, plain, and rectangular. The projecting tripata kumuda rests on the jagati. Over the tripatta a plain pattika that is a flat band is placed. Pattika is interposed between kantha mouldings. The kantha is divided into several galapadas on which the vedi the top most molding of the adhisthana composed of a padmavajana and prati seen. The prana which is fixed on the northern side of the adhisthana, appears to come out of the open mouth of a vyala. It rests on the seated image of Sankanidhi. It serves to discharge the abulution water from the garbhagriha. The excellence of this work can be seen in the Brihadisvarar temple at Thanjavur.

The bhitti or the wall portion of the sanctum sanctorum above the vedi is carrying three devakoshthas on the north, west, and the south. These niches are filled with high relief stone images

\footnotetext{
1 A.R.E., 408 of 1903; S.I.I., VIII, No. 724.

2 Ibid., 426 of 1983; Ibid., No. 742.

3 Ibid., 6 of 1922.

4 Ibid., 1 of 1922.

5 Ibid., 24 of 1922.

6 Ramanachandran, G., Karur Sthala Varalaru, Karur, p. 23.
}

of Dakshinamurti on the south, Lingodbhavamurti on the west, and Brahma on the north.

The bhitti portion is remarkable for the disposition of eighteen Brahma Kantha pilasters six on each side. The Brahma Kantha pilasters are made simply without any embellishments. The square shafts came with malasthana on the top decorated with floral scrolls and pearl strings. Above the malasthana, a band of straight and inverted lotus petals known as padmabandha is arranged. The vase-shaped kalasa is delicately adorned by festoons and fixed on the padmabandha. The intervening part called tadi separates the kalasa and kambha. The petals of a blossomed lotus (padmatala) are spread around the Kumbha. The petals are supporting the thick square palagai with virakanda. The roll corbel at the top is throated with the median band (tarangu potika) and the cross corbels of similar type in the cantering pilasters. The cantering pilasters carry the double corbel. The pilasters are well in line with vari or the axial line of adhisthana.

The portion rising above the corbels is known as prastara. It is the roof of the vimana, which connects the sanctum sanctorum and its superstructure. The prastara is consisted of the usual moldings such as bhutavari, kapota, and yalivari on the corbels carry uttara. This is not equal in width and height to the corbels found below. A vajana comes over this and has intervening panels of figural miniatures corresponding with the pilasters below. It is decorated with a frieze of ganas. Above the vajana, kodungai is found with nasikas beautified by scrollwork ornamentations with empty interior circles. The row of circles (circular boses the prototype of nail heads in wooden architecture) runs along its lower edge is the characteristic feature of the Chola architecture? Each corner of the cornice ends with a beautiful scroll designs (kodikkarukku). The cella is constructed with granite stones right from the upapitha to the prastara.

The adhisthana mouldings in this garbhagriha are of the simplest type, devoid of any ornamentation. This, together with other features like the massive pilasters and taranga potika, may give it an early date. The earliest inscription of this temple found on the walls of garbhagriha is dated to Parantaka I, and it does not refer to the construction of the central

7 Joveau Dubrevil, Dravidian Architecture, 2006, p.11. 
shrine. Hence it can be ascribed to $9^{\text {th }}$ century A.D. The tapering superstructural part of the central shrine is built of bricks. Above the roof, one can notice an ekatala vimana, square in plan. A hara of miniature pavilions such as the karnakutas in the extreme corners, the bhadrasalas in the middle, and the panjaras in between the salas and karnakutas runs round the harmya of the ekatala. The salakoshtas are devoted to figures of Uma Mahesvara in the east, Dakshinamurti with his sages in the south, Brahma with his consorts in the north, and Vishnu with his consorts in the west. Eight couching Nandis, two in each corner, are perched at the four corners of the pindi slab above its kapota.

The griva of the vimana is spherical with tetragonal pilasters and grivakoshtas. The figures of the grivakoshtas are the same as in the salakoshtas below. The griva is capped by an elliptical sikhara. The surface of the sikhara, the top element of the roof, is decorated with idaikattu, padmam, kattumalai, kannadi sattam, and mahapadma. The four mahanasikas crowned by simhavaktra and intervening nasikas are presented on the sikhara in the four directions. Above the sikhara, a single copper stupika is placed with padmaptri, kumbha, nalika, and mukula. The superstructure over the garbhagrigha has completely been renovated and replastered in the present century.

\section{Antarala}

There are two antaralas in which one connects the garbhagriha and the ardhamandapa another one the ardhamandapa the mukhamandapa. The flat roofed antarala has the same type of the external features in continuation of that of the vimana of the central shrine. The walls of the antarala have two niches, one on the north and the other on the south. The niches carry the images of Bhikshatanas on the South and Durga on the north in their respective niches.

\section{Ardhamandapa}

There are two ardhamandapas adjoining the front part of the antarala with an entrance of 1.10. $\mathrm{m}$. and $2.00 \mathrm{~m}$. Height on their eastern ends. They are intended for keeping the puja materials: The four central pillars of the front ardhamandapa are missing, but their corbels, with their roll ornament and central band, are intact. The rear ardhamandapa is supported by four rudrakanta pillars consisting of a base, shaft, and capital. The square appears to hold the bottom of the pillar - a reminder of wood and bamboo constructions where this device served as a protection against termites. On this, the inverted lotus moulding is found. The shaft of the pillar is round in shape. The topmost part of the pillar is the potika, circular at the edges with taranga ornamentation, and a patta (flat median band). The external configuration of the walls is similar in style to that of the garbhagriha. The adhisthana shows only the jagathi portion. The rest of the adhisthana is not seen. The niches are absent on the bhitti portion.

\section{Mukhamandapa}

The mukhamandapa found in front of ardhamandapa is of $6.50 \mathrm{~m}$ in length, $13.00 \mathrm{~m}$. In width, and $4.00 \mathrm{~m}$. In height is open on the eastern side. In front of this mandapa the steps protected on the sides by elephant trunk-like balustrades are provided to enter this mandapa. Four rudrakantha pillars (h $2.15 \mathrm{~m}$.) have tarangapotika corbel standing in 2 rows with two pillars in each row, shouldering the flat roof of this mandapa. The features of the exterior portions are perhaps similar to those of the ardhamandapa. The central shrine entrance is flanked by two Dvarapalakas. The Vinayaka and Adhikaranandhi on the south and Muruga on the north are found.

\section{Mahamandapa}

The rectangular mahamandapa lies next to the Mukhamandapa with a flat topped roof supported by pillars. These pillars are $2.15 \mathrm{~m}$ height. We see the two types of pillars employed here the circular and square in characters. The crowning member of the pillars is heavy bevelled corbels with prominent with tenon like projections. The pillars carry a horizontal beam lending support to the superstructure. The square type of pillar composed of three sadurams (square) and two octagonal intervening portions. This mandapa is closed by walls on the three sides and opened on the south side. It has a porch approached by a flight of steps on the south east and south west corners of this mandapa decorated with balustrades.

Below the adhisthana there must have been an upapitha that is evidently buried in the inner flooring. The bottom-most layer of adhisthana is 
upana which is plain without any ornamentation. This upana is followed by urdhva padma. Then comes vrttakumuda with padmadala followed by vyala vari. Over it is the bhitti portion is plain.

Niches and pilasters are absent in the walls. The wall is capped by ribbed mouldings of uttara, padma, and hanging inverted kodungai with kudu profiles inset with gandharvamukha on its key holes. A balipitha and a Nandi are furnished in the middle of the mahamandapa. The walls of this mandapa are filled with inscriptions ${ }^{8}$. From these inscriptions, one may presume that this mandapa is datable to the $12^{\text {th }}$ century A.D. The ceilings of this mandapa filled a covered with murals depicts the puranic history of this temple.

\section{Tiruchchurrumaligai (Cloister)}

There is a cloister with a base around the central, and the subsidiary shrines with a sacred wall of an enclosure surrounding it. The inner side of the first prakara, surrounding the shrines of Vinayaka, Muruga and Lingas in the west, Nalvar mandapa in the south as well as the large paved courtyard has a Palliarai in the north-east is in one long row of pillar cloister with cells at intervals for these deities some of which have mandapas in front. The pillars of the cloister have a round cross-section and bear heavy bevel shape, and tenon like corbel sat on the top. In the cloistered hall, all along with one confined several sculptures. The southern side has Nalvar, Bronzes, Skanda, Saptamatrikas, and Nayanmars. The western side of the cloister has Vinayaka, Sahasralingam, Sattanathar, Linga, Muruga, and Gajalakshmi. On the eastern side, there are two sculptures, namely Bhairava and Surya. This pillared cloister around the entire main shrine seems to be of $11^{\text {th }}$ century A.D.

\section{Palliarai}

To the northeast of the inner prakara is the Palliarai. It is rectangular on plan facing south. The entrance to this Palliarai has a flight of steps decorated with balustrades. The adhisthana of Palliarai consists of three stepped upana, jagathi in the form of the Padma of a smooth Vritta kumudha, and two rows old kanthas interspersed by a kapota molding carrying $k u d u$ arches. The wall which raises above the adhisthana contains two niches one

8 A.R.E., 42 of 1922; S.I.I., Vol. VIII, No. 745. on either side of the entrance. The right side niche carries a sculpture of Achyutadevar. It is small in size than the niche. The left side niche is empty. These niches flanked by sala sikhara arches. The pilasters are well in line with the vari of the axial line of the adhisthana. They consist of Nagarpadma base, octagonal shaft, malathorana, adaikkattu, kalasa, kumbha, idal, and phalaka surmounted by pushpa potika type. This corbel indicates the slow and gradual transition to the next age of evolution, with the central tenon assuming a campanulate floral form, the precursor of the puspha potika of the later period. The prastara over this consists of uttara, padma, and kapota with kudus decorated by scroll designs and simhamukha finals at the top.

The pillared hall preceding the Palliarai contains two rows of two double columns four or on each row eight pillars. They are mostly composite nature (anivettikkal), showing well-developed pushpa potika corbels. The main part of the pillars is square with three sadurams and two hexagonal or fluted intervening portions. The square portions are filled with scrolled designs and the images of gods and goddesses. The base of the additional part adjoining the main pillar is formed with two parts. Over this, we can witness a lengthy portion $\mathrm{kal}$ with nagabandha, square shaft, muthutorana, padmabanda, kalasa, tadi, kumbam, idal, palagi. Over the palagi we can notice a lotus flower motif. Beyond that there is a kantha with galapada. Then, there seems two lions with open mouth in standing position. This simple and elegant Palliarai seems to have been built round during the $12^{\text {th }}$ century A.D.

\section{Natana Sabha}

In between the mukha mandapa and maha mandapa is the beautiful shrine for Lord Nataraja (Natana Sabha). The shrine faces south. This mandapa has a cell and porch approached by a flight of steps on the south side decorated with balustrades. There is no tower over the cell. The Vijayanagar rulers that are, Harihara $\mathrm{II}^{9}$ and with balus traders. Devaraya ${ }^{10}$ engraved their inscriptions on the walls. So this shrine was probably built during fourteenth century A.D. Architectural features of this shrine are also proved this fact. In the center of the cell, there is a

9 Ibid., 31 of 1922.

10 Ibid., 33 of 1922. 
platform adjacent to the northern wall. This platform is decorated with adhisthana mouldings. We see the adhisthana mouldings still retaining their simplicity with only a few additional lotus-petal ornamentations. The bottom-most fillets constitute the upana, over it on the vertical plane or the adhopadma mouldings, then a plain kanta, Virthakumuda again a plain kanta, urdhvapadma and finally the prati. There are four pillars raised on the four corners of the platform. The pillars are square with three square portions and two hexagonal or fluted intervening portions. The pillar capital bears pronounced chamfered corbels. The cornice is thick and straight. The porch also has same type of two square pillars.

\section{Cloister in the Second Prakara}

The Thirumaligai portion of the second prakara is a raised structure and is found on the south and western sides of this prakara. It is now in dilapidated condition. It has a single storey supported by rudrakantha pillars with tenon-boss corbel. From its style, this cloister can be ascribed to the $11^{\text {th }}$ century A.D. There is a separate shrine for Ramar in middle of the southern cloister. The shrines of Siddhi Vinayaga, Ramar, and Sivapuja Vinayagar in southern prakara, Valamburi Vinayaga, Annamalaiyar, Arumuga, and Vayalinga in the western prakara, Esanya Linga, and Yaga salai mandapa the later additions, are found in eastern side of second prakara.

\section{Sub shrines}

In large temples, there are several subsidiary shrines around the central shrine called parivaralayas around the central meant for parivara devatas. During the Pallava period, these shrines were attached to the middle of the south, north, and western side walls of the garbhagrha. These can be observed in the Kailasanatha temple at Kanchipuram ${ }^{11}$ and Talagirisvarar temple at Panamalai. ${ }^{12}$

During the early Chola period, sub shrines were demarcated from the central shrine and formed separate shrines in the prakara. In the succeeding periods, the number of these shrines were increased commensurate with the formation of the main temple. It can be seen that in Karur Abhirameswarar

11 Srinivasan, K.R., Temples of South India, 1972, p.115. 12 Venkatesan, N., Pallavan Kanda Panaimalai Koil, Madras, 1990, p.31. temple, various sub-shrines are located admirably in the second prakara.

\section{Siddhi Vinayaga Shrine}

Siddhi Vinayaga shrine, built as an independent structure, is situated on the southern side of the second prakara. This shrine consists of square cell preceded by rectangular mandapa. The cell is intended for housing Siddhi Vinayagar. This shrine is near Ramar shrine and Sivapuja Vinayagar shrine.

This shrine faces east. It consists of a garbhagriha and mukhamandapa. The adhisthana of the vimana is the padabandha adhisthana consists of upana, jagathi, tripattakumudha, kantha, pattika, again kantha, padma vajana, and kampa. The pilasters on the wall contain rectangular base (kal), a padmabandam, kalasam, tadi, kumudam, and a thin square palagai is surmounted by pushpa potika capital. The niches are absent here. The prastara above the capital carries the Padma vari, kodungai with kudus, and vyala vari. Above this vari, griva is found, which is rounded in shape. Its grivakosthas are occupied by Vinayaka figures. Over the griva a round-shaped sikhara is placed. Above this, we can notice a copper platted stupika.

The pillared hall preceding this mandapa contains two rows of square pillars. The corbel above them shows Pushpa potika decoration that is typical of the Vijayanagar potikas. Hence this shrine was built in the $14^{\text {th }}$ century A.D Another Vinayaga shrine is dedicated to Sivapujai Vinayaga. It is just back to the Siddhi Vinayaga shrine facing north. It reflects the same architectural features of the Siddhi Vinayaga shrine.

\section{Arumuga Shrine}

It has a square sanctum, an antarala and a mukha mandapa. The sanctum is crowned by a vimana, about $25 \mathrm{ft}$ in height. It is dedicated to Lord Arumugha and his consorts Valli and Deivanai. This shrine seems to have been built sometime in the $13^{\text {th }}$ century A.D. The earliest reference to the shrine is found in a record ${ }^{13}$ dated A.D. 1256 belonging to Kopperunjinga II. It registers the installation of the Subrahmanya image by Kuntramduthan Vanathirayan Vairathirayam Udaiyan in this temple.

The adhisthana of the entire structure is composed

13 S.I.I, Vol. XII, No. 181. 
of upana, jagathi, tripatta kumuda, lower kanta, pattika and upper kanta. The wall space is decorated by brahmakanta pilasters, having bevelled and tenon like corbel. There are altogether five niches - two on the sides and one on the real wall. The niches are surmounted by makaratorana without usual miniature relief sculptures. The prastara is renovated in the modern times.

\section{Dwarf Gopura}

"Gopura" is a Sanskrit word meaning a towering gateway of a town or temple. ${ }^{14}$ It is considered as the stularupam or gross form of divinity and hence regarded as efficacious as the garbhagrha. This consists of a structure which was rectangular in ground plan with a huge entrance and had receding stories rising into several floors ${ }^{15}$ in the Dravidian style of architecture. Generally, gopuras are erected over one or more of the cardinal points of a temple and the number of gopuras upon the number of enclosures.

Manasara, the basic literary work on architecture, has devoted some chapters from the $29^{\text {th }}$ to the $31^{\text {st }}$ for giving the various gradations or sizes and the parts of the gopura. Yet another work, Mayamata, narrates the various nams of gopuras based on the number of storeys, Dvaragopuram consisting of seven to sixteen storeys. Besides these works Vaikanasa, Isanasivagurudeva, Paddhati and the like all pertaining to the architecture, deal with the gopura.

Till the $7^{\text {th }}$ and $8^{\text {th }}$ centuries A.D., there was no indication of gopura that was the special feature of Dravidian style of architecture. But still the foundation of such constructions composing gopuras exists in some Indian literary works and monuments.

In Vedic times, there was gamadvara, a huge entrance to the barbican around the village. This entrance offered protection to cows and was the access through which the cattle returned after grazing in the field and hence it was called go (cow), pura (dvara) or cow - gate. ${ }^{16}$

14 Velusamy Suthanthiran, "Evolution of Gopura in Temple Architecture of Tamil Nadu," Journal of Tamil Studies, 35, 1989, p. 28.

15 Raman, V., Gopuram, Vazhviyar Kalanjiyam, 1991, p. 162.

16 Percy Brown, Op.cit., p. 3.
The word gopura was first recorded in Ramayana $^{17}$ and Mahabharatra ${ }^{18}$ to mean the gateway to the town. In the Buddhist chaityas and viharas, the gopura can be seen on the gateway determined on the cardinal points but its shape is different. It was marked by the terracotta figures and called toranas. The best examples of these are found in Sanchi stupa. ${ }^{19}$

The panels of Amaravati and Nagarjunakonda depicted city walls pierced by large gateways topped by salas. It can be understood that South Indians had konwn about the gopura as early as the first and second centuries. A.D. ${ }^{20}$

In Sangam literary works, mention of the entrances and ramparts are found but no references to the temple gateways. ${ }^{21}$ The origin of the gopuras is traced back to the early structures of the Pallavas. In the Kailasanatha temple of Rajaraja I gave a new direction by constructing two gopuras in front of the vimana of Brihadisvarar temple at Thanjavur. From the time of Kulottunga I four gopuras were raised on the four sides of Rajasimha, Dvaracalai is seen above the entrance. This Dvaracalai served as a prototype for the later developed gopuras. ${ }^{22}$

Under the Cholas, gopuras developed and contained a few tiers designed with sculptures. Rajaraja I gave a new direction by constructing two gopuras in front the vimana of Brihadisvarar temple at Thanjavaur. ${ }^{23}$ From the time of Kulottunga I four gopuras were raised on the four sides of enclosures each in one direction. ${ }^{24}$

In the initial stage of architectural history of Tamilnadu, gopura was of a modest size in a place secondary to that of vimana but at the later stages the process took place in the reverse direction. From the period of the Pandays, special attention was given to the construction of gopuras imposing in their mature form. These gopuras became as mighty as the 17 Havell, E.B., Op.cit., p. 31.

18 Harle, J., Temple Gateways in South India, Oxford, 1963, p. 1.

19 Gopura, Encyclopedia of Indian Culture, 1983..

20 Raman, V., op.cit.,

21 Thirumanthiram, 1792.

22 Percy Brown, Indian Architecture, Bombay, 1971, p. 82.

23 Balasubramanian, S.R., Four Chola Temples, Thiripathi, Bombay, 1963, p. 41.

24 Ibid., p. 54. 
Chola vimanas. The glorious examples of these are Jambukesvara temple at Tiruvanaikka, the western gopura of the Chidambaram temple, the gopura at Kumbakonam, and the eastern gopura of Tirumalai. ${ }^{25}$

Under the Vijayanagar rulers, the gopura reached its maturity. Madurai, Kanchipuram, Chidambaram, Tiruvannamlai and Srirangam temple gopuras are typical examples of this period. ${ }^{26}$ The Nayaks lavished most of their skills and resources on the architecture of the gopuras. The highly ornamented gigantic gopuras of Nayaks can be seen in the Madurai Minakshi temple, Ranganatha temple of Srirangam, Ramesvaram temple, Srivilliputtur temple and other temples in the south. ${ }^{27}$

Generally gopura is an entrance of passageway through its interior where the templehas an access. The passageway runs to the main cornice and bifurcates the portion into two equal and separate portions. Normally the entryway has its height and width in the ratio of 2:1. The entryway in almost all gopuras has two dvaras at an equal distance from the outer and inner entrances respectively. They are in fact doorways or doorframes and not doors.

The jambs and lintels of varying sizes are invariably monolithic. The sills are of a single piece of stone as far as possible. The central portion of the entry is a separate unit located in between the dvaras. But it a ceiling different form that of the rest of the entry necessarily a bit higher.

Two identical rooms flanking the central portion open into and they are called vestibules. They are deep recesses than rooms. At no point in the entryway they are wider or higher than their opening. Vestibules in larger gopuras are divided into two storeys of more or less identical height. A pair of columns normally support the floor of The upper vestibules and from there the upper storeys of the gopura may be reached through a flight of stairs. Normally the floors of the lower vestibules upper vestibule rise to about four feet above the level of the entryway. Around each

25 Percy Brown, op.cit., p. 89.

26 Ibid., pp. 91-94.

27 Ibid., pp. 95-100 vestibules a corridor runs circumambulatory or semi circumambulatory internally as could be seen from some of the earlier gopuras.

Huge pilasters line the side walls of the entryway, save in the central portion. The massive lintels forming the ceiling of the entryway are supported by the pilasters which are usually grouped in clusters. A series of super-imposed kapotas with bas relief plaques representing dancers, salabhanjikas, or other figures inserted in between them are found in the later gopuras.

\section{Conclusion}

Typical of the later South Indian temple structures, the upper storeys of gopura are of brick, plaster and stucco whereas the portions continue to be of stone. The upper storeys formed a pylon shaped tower and crowned by a barrel vaulted roof with a series of kalasas. They comprise pavilions clustered around the central mass of the structure. The pavilions are so arranged as to correspond to the bays and recesses of the main storey. There are oblong pavilions above the wider bays and square pavilions at the corners. The upper storeys are crowded by life sized and more than life sized statues of stucco or terracotta. Due to impermanence of materials the upper storeys of gopura had to be restored periodically. Some gopuras have upper storeys constructed as a single unit whereas some others have them floor by floor. In both cases the method of construction basically is corbelling with bricks. Above the entryway every storey has a large opening in every storey on each side. Gopuras have an uneven number of storeys as well as uneven number of finials. There are two gopuras in Kalyanapasupatheswarar temple at Karur, one in the middle of the western side and eastern side and the other in the middle of the western side of the second prakara aligned on the east-westst axis to the main shrine. Out of the two gopuras, the seven storeyed Rajagopura placed on the entrance gateway enclosing the second prakara is considered to be larger and volumes as well as in aesthetic appearance.

\section{Author Details}

Dr.P.Suresh Kumar, Assistant Professor, Department of History (SF), Kandasami Kandar's College, Paramathi Velur, Namakkal, Tamil Nadu, India. 